\title{
Prevalence and barriers of providing written asthma action plan by primary care physicians in Saudi Arabia (2019); a multivariate regression analysis
}

\author{
Omar Mousa Alshamrani ${ }^{1}$, Sultan Musaed Albalawi ${ }^{1}$, Ayman Afify ${ }^{2}$, Mustafa Kofi ${ }^{3}$
}

${ }^{1}$ MD, Resident, Family and Community Medicine Department, Prince Sultan Military Medical City (PSMMC), Riyadh, Saudi Arabia

${ }^{2}$ MD, Consultant Family Medicine and EBM, Al-Wzarat Health Center, PSMMC, Riyadh City, Saudi Arabia

${ }^{3}$ MD, Consultant Occupational Medicine, Head Research Unit, Family and Community Medicine Department, PSMMC, Riyadh City, Saudi Arabia

\section{Type of article: Original}

\begin{abstract}
Background: Personalized written asthma action plans (WAAP) can assist self-management of asthma and improve management outcomes. In Saudi Arabia, data assessing the adherence with providing WAAP are decidedly lacking.

Objective: To determine the prevalence of providing WAAP and its perceived barriers by family physicians.

Methods: A cross-sectional study was conducted among family physicians working in family medicine clinics of Prince Sultan Military Medical City (Riyadh, Saudi Arabia) during November 2019. Physicians were asked to fill in a researcher-made study questionnaire that included potential WAAP barriers. IBMC SPSSC Statistics version 21 was used for statistical analyses.

Results: Out of 202 physicians included in the current study, only $34(16.8 \%)$ were providing WAAP for their patients with asthma. Only $6.8 \%$ of the patients seen by the study physicians were receiving WAAP. In multivariate logistic regression analysis, larger number of patients encountered per month and non-adherence of patients to management plans were significantly associated with providing WAAP. Odds ratios (OR) were "OR: 1.02, 95\% CI: $1.01-1.04, \mathrm{p}=0.009$ " and "OR: $3.33,95 \% \mathrm{CI}: 1.40-7.87, \mathrm{p}=0.006$. On the other hand, lack of awareness with WAAP recommendations was significantly associated with not providing WAAP (OR: $0.19,95 \%$ CI: 0.04-0.89, $\mathrm{p}=0.035$ ).

Conclusions: The finding confirms the low utilization of WAAP at primary care setting in Saudi Arabia, which is probably reflecting a limited education and training rather than a negative attitude towards WAAP. The findings underscore the need to raise the awareness of family physicians with WAAP recommendations and the need to fix some workflow issues.

Keywords: Written asthma action plans, Physician, Bronchial asthma, Utilization management, Primary care, Saudi Arabia
\end{abstract}

\section{Abbreviations / Acronyms:}

PSMMC: Prince Sultan Military Medical City, WAAP: Personalized written asthma action plan

\section{Introduction}

Bronchial asthma is the most prevalent chronic respiratory disease worldwide (1). Its burden has been increasing globally in the last two decades (1). Asthma causes significant mortality, morbidity, disability, and financial burden for patients, families, and healthcare systems $(1,2)$. Proper asthma management is highly influenced by early and accurate diagnosis (3). Additionally, asthma management should be individualized based on age, underlying etiology, severity of symptoms, and response to medications $(3,4)$. The prevalence of asthma in Saudi Arabia is thought to be slightly higher than international rates and is considered one of the highest rates in the Middle East (5, 6). Additionally, the prevalence of uncontrolled asthma among asthmatic patients is still unacceptably high; 59.3\%

\section{Corresponding author:}

Ayman Afify. Al-Wzarat Health Center, Prince Sultan Military Medical City, Riaydh, 21577, Saudi Arabia. Tel: +96-508632196, E-mail: iymen16@gmail.com

Received: July 02, 2020, Accepted: August 18, 2020, Published: September 2020

iThenticate screening: August 17, 2020, English editing: September 14, 2020, Quality control: September 14, 2020

(C) 2020 The Authors. This is an open access article under the terms of the Creative Commons Attribution-NonCommercialNoDerivs License, which permits use and distribution in any medium, provided the original work is properly cited, the use is non-commercial and no modifications or adaptations are made. 
in children and $68 \%$ in adults (7-9). This may reflect the suboptimal adherence of both patients and physicians with asthma management guidelines (10-12). According to national and international guidelines, patients with asthma should be provided with an individualized written asthma action plan (WAAP) to improve self-management $(3,4)$. The use of WAAP has been associated with improved patients' knowledge about asthma and its management, improved quality of life, and reduction of asthma exacerbation and emergency visits (13-15). Nevertheless, the use of WAAP at primary care setting is still unacceptably low in many countries (16-19). Several factors have been put forward as to why physicians are discouraged from providing WAAP for their patients, such as pressure of time, lack of resources, and inadequate awareness of physicians $(20,21)$. In Saudi Arabia, there is an absolute lack of studies assessing the adherence of primary care physicians with providing WAAP and its influencing factors. In an effort to improve asthma management at primary care setting at the Prince Sultan Military Medical City (PSMMC) and to assess the adherence of primary care physicians with WAAP use, we thought to determine the prevalence of providing WAAP and its barriers as perceived by family physicians.

\section{Material and Methods}

\subsection{Research design and setting}

It was a cross-sectional study conducted during November 2019. The study was conducted at 15 family medicine centers at PSMMC. These centers are distributed in all regions of Riyadh, Saudi Arabia. Both triage and booked clinics were included. Each primary health care center at PSMMC consists of several general clinics, pharmacy, laboratory, treatment room and radiology room. The centers provide free primary care services, including diagnosis and basic treatment of acute and chronic diseases, maternal and child health, immunization for communicable diseases, screening for several healthcare problems, and health education and promotion.

\subsection{Study population}

The study targeted family physicians working in family medicine clinics during November 2019, who were willing to participate in the study irrespective of their age, gender, nationality, and professional category. Non-clinical physicians such as administrators and those in specialties not likely to manage patients with asthma were excluded.

\subsection{Sample size and sampling}

Previous studies done internationally showed a wide variability of the prevalence of using WAAP by family physicians which ranged between 4\% and 39\% (16-19). It was then estimated that approximately 196 physicians would be required to detect a WAAP prevalence of $20 \%$ with two-sided confidence limits of $5 \%$, using $80 \%$ power level and $95 \%$ two-sided significance level. Since the number of target family physicians was limited, all family physicians at PSMMC were approached using a convenience sampling technique. They were reached directly at their centers during clinic times. Included physicians were asked to sign informed consent after explaining the objectives of the study and before data collection.

\subsection{Instrument, validity and reliability}

The data were collected using a researcher-made structured study questionnaire (Table 1). This included data on socio-demographic characteristics, professional and clinical characteristics, and the barriers for providing WAAP for patients with asthma. The questionnaire was self-completed by the physicians. The face (how much questions cover the study objectives) and content validity (scientific merit of questions) of the questionnaire were evaluated by three experts in family medicine, asthma, and research. The questionnaire was slightly modified based on the expert suggestions. The barrier part of the questionnaire had high reliability with Cronbach's alpha of 0.809 .

\subsection{Statistical analysis}

Categorical variables were presented as frequencies and percentage while continuous variables were presented as means and standard deviations (SD). Socio-demographic characteristics, professional and clinical characteristics, and the barriers for providing WAAP were compared between physicians who were and those who were not providing WAAP for asthma patients. Chi-square or Fisher's exact test, as appropriate, were used to detect significant differences in categorical variables while student t-test or Mann-Whitney test, as appropriate, were used to detect significant differences in continuous variables. To identify factors independently associated with providing WAAP, multivariate logistic regression analysis models were run after adjusting for the variables that were significantly associated with providing WAAP in univariate analysis. All P-values were two-tailed. P-value $<0.05$

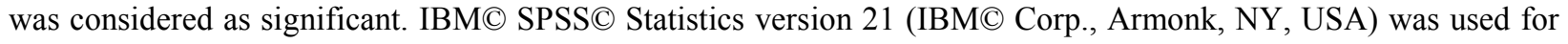
all statistical analyses.

\subsection{Ethics of research}

The study design obtained all required ethical approvals from the ethical committee of PSMMC. 
Table 1. Questionnaire and data collection form

\begin{tabular}{|c|c|c|c|c|c|c|c|c|c|}
\hline \multirow{8}{*}{$\begin{array}{l}\text { Demographic } \\
\text { data }\end{array}$} & \multicolumn{9}{|l|}{ Age (years) } \\
\hline & Nationality & Saudi & \multicolumn{7}{|c|}{ Non Saudi } \\
\hline & \multirow{3}{*}{$\begin{array}{l}\text { Gender } \\
\text { Marital status } \\
\text { Job title }\end{array}$} & Male & \multicolumn{7}{|l|}{ Female } \\
\hline & & \multicolumn{2}{|l|}{ Married } & \multicolumn{2}{|l|}{ Single } & \multicolumn{2}{|c|}{ Divorced } & \multicolumn{2}{|c|}{ Widowed } \\
\hline & & Consultant & $\begin{array}{l}\text { Senior } \\
\text { registrar }\end{array}$ & Registrar & SHO & $\mathrm{R} 1$ & $\mathrm{R} 2$ & R3 & $\mathrm{R} 4$ \\
\hline & Experience (year) & & & & & & & & \\
\hline & Family history of asthma & Yes & No & & & & & & \\
\hline & $\begin{array}{l}\text { Working clinic (most of the } \\
\text { times) }\end{array}$ & Booked & Triage & & & & & & \\
\hline \multirow[t]{6}{*}{ Practice } & $\begin{array}{l}\text { Do you usually manage } \\
\text { patients with asthma? }\end{array}$ & Yes & \multicolumn{7}{|l|}{ No } \\
\hline & $\begin{array}{l}\text { How many patients with } \\
\text { asthma have you seen in } \\
\text { the last month? }\end{array}$ & Yes & \multicolumn{7}{|l|}{ No } \\
\hline & $\begin{array}{l}\text { Have you ever provided } \\
\text { WAAP for your patients } \\
\text { with asthma? }\end{array}$ & Yes & \multicolumn{7}{|l|}{ No } \\
\hline & $\begin{array}{l}\text { How often do you provide } \\
\text { WAAP for your patients } \\
\text { with asthma? }\end{array}$ & Always & $\begin{array}{l}\text { Most of } \\
\text { times }\end{array}$ & \multicolumn{3}{|c|}{ Sometimes } & & \multicolumn{2}{|c|}{ Never } \\
\hline & $\begin{array}{l}\text { How many patients have } \\
\text { you given a WAAP in the } \\
\text { last month? }\end{array}$ & Always & $\begin{array}{l}\text { Most of } \\
\text { times }\end{array}$ & \multicolumn{3}{|c|}{ Sometimes } & & \multicolumn{2}{|c|}{ Never } \\
\hline & $\begin{array}{l}\text { How often do you refer } \\
\text { your patients with asthma } \\
\text { to asthma educator? }\end{array}$ & Always & $\begin{array}{l}\text { Most of } \\
\text { times }\end{array}$ & \multicolumn{3}{|c|}{ Sometimes } & & Never & \\
\hline \multirow{12}{*}{$\begin{array}{l}\text { Barriers } \\
\text { (According to } \\
\text { your } \\
\text { experience, } \\
\text { what are the } \\
\text { barriers for } \\
\text { providing } \\
\text { WAAP for } \\
\text { patients with } \\
\text { asthma?) }\end{array}$} & $\begin{array}{l}\text { There is no time to write it } \\
\text { in the clinic }\end{array}$ & \multicolumn{2}{|c|}{ Strongly agree } & Agree & Neutra & \multicolumn{3}{|c|}{ Disagree } & Strongly disagree \\
\hline & High workload & \multicolumn{2}{|c|}{ Strongly agree } & Agree & Neutra & \multicolumn{3}{|c|}{ Disagree } & Strongly disagree \\
\hline & $\begin{array}{l}\text { Materials (forms) are not } \\
\text { available in the clinic }\end{array}$ & \multicolumn{2}{|c|}{ Strongly agree } & Agree & Neutra & \multicolumn{3}{|c|}{ Disagree } & Strongly disagree \\
\hline & $\begin{array}{l}\text { Arabic version of materials } \\
\text { (forms) are not available in } \\
\text { the clinic }\end{array}$ & \multicolumn{2}{|c|}{ Strongly agree } & Agree & Neutra & \multicolumn{3}{|c|}{ Disagree } & Strongly disagree \\
\hline & $\begin{array}{l}\text { I am not trained to use } \\
\text { WAAP }\end{array}$ & \multicolumn{2}{|c|}{ Strongly agree } & Agree & Neutra & \multicolumn{3}{|c|}{ Disagree } & Strongly disagree \\
\hline & $\begin{array}{l}\text { I am not aware about the } \\
\text { recommendations for } \\
\text { providing WAAP }\end{array}$ & \multicolumn{2}{|c|}{ Strongly agree } & Agree & Neutra & & Disagre & & Strongly disagree \\
\hline & $\begin{array}{l}\text { I think that verbal } \\
\text { instructions is enough for } \\
\text { my patients }\end{array}$ & Strongly ag & & Agree & Neutra & & Disagre & & Strongly disagree \\
\hline & $\begin{array}{l}\text { This is the work of Asthma } \\
\text { educator }\end{array}$ & Strongly ag & & Agree & Neutra & & Disagre & & Strongly disagree \\
\hline & This is the work of nurse & Strongly ag & & Agree & Neutra & & Disagre & & Strongly disagree \\
\hline & $\begin{array}{l}\text { Majority of my patients } \\
\text { have low level of education }\end{array}$ & Strongly ag & & Agree & Neutra & & Disagre & & Strongly disagree \\
\hline & $\begin{array}{l}\text { Majority of my patients are } \\
\text { not adhering to the plans }\end{array}$ & Strongly ag & & Agree & Neutra & & Disagre & & Strongly disagree \\
\hline & $\begin{array}{l}\text { The WAAP is not } \\
\text { beneficial for the patients } \\
\text { with asthma }\end{array}$ & Strongly ag & & Agree & Neutra & & Disagre & & Strongly disagree \\
\hline
\end{tabular}




\section{Results}

A total 202 physicians were included in this analysis. Out of 202 physicians, only $34(16.8 \%)$ were providing WAAP for their patients with asthma. The socio-demographic characteristics of the included physicians by the status of providing WAAP are shown in Table 2 . The average age was $37.2 \pm 10.4$ years, with almost half of the physicians being less than 35 years $(48.3 \%)$. Males were slightly more represented than females $(56.3 \%$ versus $43.7 \%$, respectively). Almost two-thirds $(63.9 \%)$ of the physicians were Saudi. The majority $(78.1 \%)$ of the physicians were married, followed by single (21.4\%), and finally divorced $(0.5 \%)$. Only $36.1 \%$ of the physicians reported family history of asthma. Age and nationality were significantly associated with providing WAAP. For example, those who were providing WAAP had older age than those who did not provide WAAP $(41.7 \pm 10.4$ versus $36.3 \pm 10.2, \mathrm{p}=0.006$ ). Non-Saudis represented $52.9 \%$ of those who were providing WAAP and $32.7 \%$ of those who did not provide WAAP $(\mathrm{p}=0.025)$.

Table 2. Demographic characteristics by the status of providing written asthma action plan (WAAP) for patients with asthma $(\mathrm{n}=202)$

\begin{tabular}{|c|c|c|c|c|c|}
\hline \multirow{2}{*}{\multicolumn{2}{|c|}{ Variables }} & \multicolumn{2}{|c|}{ Ever providing WAAP } & \multirow{2}{*}{$\begin{array}{l}\text { Total } \\
(\mathrm{n}=202)\end{array}$} & \multirow[t]{2}{*}{ p-value } \\
\hline & & No $(n=168)$ & Yes $(n=34)$ & & \\
\hline \multirow[t]{5}{*}{ Age (years) } & Mean \pm SD & $36.3 \pm 10.2$ & $41.7 \pm 10.4$ & $37.2 \pm 10.4$ & 0.006 \\
\hline & $<35$ & $88(52.7 \%)$ & $9(26.5 \%)$ & $97(48.3 \%)$ & \multirow[t]{4}{*}{0.031} \\
\hline & $35-45$ & $47(28.1 \%)$ & $14(41.2 \%)$ & $61(30.3 \%)$ & \\
\hline & $46-55$ & $22(13.2 \%)$ & $9(26.5 \%)$ & $31(15.4 \%)$ & \\
\hline & $>55$ & $10(6.0 \%)$ & $2(5.9 \%)$ & $12(6.0 \%)$ & \\
\hline \multirow[t]{2}{*}{ Gender } & Male & $93(56.0 \%)$ & $19(57.6 \%)$ & $112(56.3 \%)$ & \multirow[t]{2}{*}{0.870} \\
\hline & Female & $73(44.0 \%)$ & $14(42.4 \%)$ & $87(43.7 \%)$ & \\
\hline \multirow[t]{2}{*}{ Nationality } & Saudi & $113(67.3 \%)$ & $16(47.1 \%)$ & $129(63.9 \%)$ & \multirow[t]{2}{*}{0.025} \\
\hline & Non-Saudi & $55(32.7 \%)$ & $18(52.9 \%)$ & $73(36.1 \%)$ & \\
\hline \multirow[t]{3}{*}{ Marital status } & Single & $37(22.8 \%)$ & $5(14.7 \%)$ & $42(21.4 \%)$ & \multirow[t]{2}{*}{0.473} \\
\hline & Married & $124(76.5 \%)$ & $29(85.3 \%)$ & $153(78.1 \%)$ & \\
\hline & Divorced & $1(0.6 \%)$ & $0(0.0 \%)$ & $1(0.5 \%)$ & \\
\hline \multirow[t]{2}{*}{ Family history of asthma } & No & $109(64.9 \%)$ & $20(58.8 \%)$ & $129(63.9 \%)$ & \multirow{2}{*}{0.503} \\
\hline & Yes & $59(35.1 \%)$ & $14(41.2 \%)$ & $73(36.1 \%)$ & \\
\hline
\end{tabular}

Table 3 shows the professional characteristics of included physicians by the status of providing WAAP. All job titles were represented with residents and registrars $(31.3 \%$ and $26.4 \%$, respectively) more frequent than other job titles. The average duration of experience was $11.3 \pm 9.3$ years. The most frequent working clinics were booked clinics $(58.4 \%)$, followed by triage clinics $(32.7 \%)$, and finally both booked and triage clinics $(8.9 \%)$. The average number of patients encountered per month was 15.5 patients (median 8 patients). Out of them, an average of 0.8 patients were provided with WAAP, which represent $6.8 \%$ of the patients encountered. The majority $(86.6 \%)$ of the physicians were managing patients with asthma. Only $14.3 \%$ were always $(2.9 \%)$ or often $(11.4 \%)$ referring their patients with asthma to an asthma educator. Providing WAAP was significantly associated with longer years of experience (14.3 \pm 9.7 versus $10.6 \pm 9.1, \mathrm{p}=0.024)$, larger number of patients encountered per month $(23.5 \pm 24.1$ versus $13.8 \pm 18.6, \mathrm{p}=0.001)$, and managing patients with asthma ( $100.0 \%$ versus $83.9 \%, \mathrm{p}=0.010)$.

Table 4 shows potential barriers for providing WAAP by the actual status of providing WAAP. Both those who

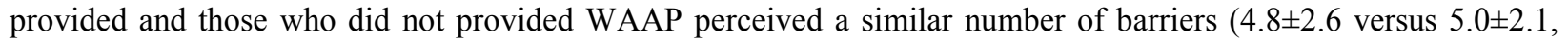
$\mathrm{p}=0.615)$. Important barriers for providing WAAP as perceived by family physicians included lack of materials (forms) in the clinic (81.3\%), lack of an Arabic version of materials (forms) in the clinic (78.9\%), high workload (74.6\%), and lack of time to write WAAP in the clinic (70.9\%). On the other hand, less important barriers for providing WAAP as perceived by family physicians included the belief that WAAP is the nurses responsibility (6.6\%), the belief that WAAP is not beneficial for the patients with asthma (7.0\%), lack of physician awareness about the recommendations for providing WAAP (21.2\%), and the belief that verbal instruction is enough for advising patients with asthma (26.5\%). Lack of physician training to use WAAP $(33.1 \%$ versus $15.6 \%$, $\mathrm{p}=0.049)$ and lack of physician awareness with WAAP recommendations $(24.2 \%$ versus $6.1 \%$, $\mathrm{p}=0.020)$ were significantly higher among those who did not provide WAAP while non-adherence of patients to the plans was significantly higher among those who were providing WAAP $(58.8 \%$ versus $38.8 \%, \mathrm{p}=0.031)$. 
http://www.ephysician.ir

Table 3. Professional characteristics by the status of providing written asthma action plan

(WAAP) for patients with asthma $(n=202)$

\begin{tabular}{|c|c|c|c|c|c|}
\hline \multirow{2}{*}{\multicolumn{2}{|c|}{ Variables }} & \multicolumn{2}{|c|}{ Ever providing WAAP } & \multirow{2}{*}{$\begin{array}{l}\text { Total } \\
(\mathrm{n}=202)\end{array}$} & \multirow[t]{2}{*}{ p-value } \\
\hline & & No $(n=168)$ & Yes $(n=34)$ & & \\
\hline \multirow{5}{*}{ Job title } & Senior house officer (SHO) & $11(6.6 \%)$ & $4(11.8 \%)$ & $15(7.5 \%)$ & \multirow[t]{5}{*}{0.155} \\
\hline & Resident & $58(34.7 \%)$ & $5(14.7 \%)$ & $63(31.3 \%)$ & \\
\hline & Registrar & $42(25.1 \%)$ & $11(32.4 \%)$ & $53(26.4 \%)$ & \\
\hline & Senior registrar & $22(13.2 \%)$ & $5(14.7 \%)$ & $27(13.4 \%)$ & \\
\hline & Consultant & $34(20.4 \%)$ & $9(26.5 \%)$ & $43(21.4 \%)$ & \\
\hline \multirow{5}{*}{$\begin{array}{l}\text { Duration of experience } \\
\text { (years) }\end{array}$} & Mean \pm SD & $10.6 \pm 9.1$ & $14.3 \pm 9.7$ & $11.3 \pm 9.3$ & 0.024 \\
\hline & $<5$ & $49(31.6 \%)$ & $6(17.6 \%)$ & $55(29.1 \%)$ & \multirow[t]{4}{*}{0.003} \\
\hline & $5-10$ & $54(34.8 \%)$ & $7(20.6 \%)$ & $61(32.3 \%)$ & \\
\hline & $11-20$ & $25(16.1 \%)$ & $15(44.1 \%)$ & $40(21.2 \%)$ & \\
\hline & $>20$ & $27(17.4 \%)$ & $6(17.6 \%)$ & $33(17.5 \%)$ & \\
\hline \multirow[t]{3}{*}{ Working clinic } & Booked & $103(61.3 \%)$ & $15(44.1 \%)$ & $118(58.4 \%)$ & \multirow[t]{3}{*}{0.070} \\
\hline & Triage & $53(31.5 \%)$ & $13(38.2 \%)$ & $66(32.7 \%)$ & \\
\hline & Both & $12(7.1 \%)$ & $6(17.6 \%)$ & $18(8.9 \%)$ & \\
\hline \multirow{3}{*}{$\begin{array}{l}\text { Monthly patients with } \\
\text { asthma }\end{array}$} & Number encountered & $13.8 \pm 18.6$ & $23.5 \pm 24.1$ & $15.5 \pm 20.0$ & 0.001 \\
\hline & Number provided WAAP & $0.0 \pm 0.0$ & $4.8 \pm 4.8$ & $0.8 \pm 2.7$ & $<0.001$ \\
\hline & Percentage provided WAAP & $0.0 \% \pm 0.0 \%$ & $39.4 \% \pm 32.8 \%$ & $6.8 \% \pm 20.1 \%$ & $<0.001$ \\
\hline \multirow{2}{*}{$\begin{array}{l}\text { Managing patients with } \\
\text { asthma }\end{array}$} & No & $27(16.1 \%)$ & $0(0.0 \%)$ & $27(13.4 \%)$ & \multirow[t]{2}{*}{0.010} \\
\hline & Yes & $141(83.9 \%)$ & $34(100.0 \%)$ & $175(86.6 \%)$ & \\
\hline \multirow{4}{*}{$\begin{array}{l}\text { Referring patients with } \\
\text { asthma to asthma } \\
\text { educator }\end{array}$} & Never & $58(41.1 \%)$ & $12(35.3 \%)$ & $70(40.0 \%)$ & \multirow[t]{4}{*}{0.441} \\
\hline & Sometimes & $65(46.1 \%)$ & $15(44.1 \%)$ & $80(45.7 \%)$ & \\
\hline & Often & $15(10.6 \%)$ & $5(14.7 \%)$ & $20(11.4 \%)$ & \\
\hline & Always & $3(2.1 \%)$ & $2(5.9 \%)$ & $5(2.9 \%)$ & \\
\hline
\end{tabular}

Table 4. Barriers for providing written asthma action plan (WAAP) for patients with asthma by the status of actual providing WAAP among included physicians $(\mathrm{n}=202)$

\begin{tabular}{|c|c|c|c|c|c|}
\hline \multirow{2}{*}{\multicolumn{2}{|c|}{ Variables }} & \multicolumn{2}{|c|}{ Ever providing WAAP } & \multirow{2}{*}{$\begin{array}{l}\text { Total } \\
(\mathrm{n}=202)\end{array}$} & \multirow[t]{2}{*}{ p-value } \\
\hline & & No $(n=168)$ & Yes $(n=34)$ & & \\
\hline \multicolumn{2}{|c|}{ Number of barriers perceived } & $5.0 \pm 2.1$ & $4.8 \pm 2.6$ & $4.9 \pm 2.2$ & 0.615 \\
\hline \multirow{12}{*}{$\begin{array}{l}\text { Specific barriers } \\
\text { perceived }\end{array}$} & There is no time to write it in the clinic & $120(72.7 \%)$ & $21(61.8 \%)$ & $141(70.9 \%)$ & 0.200 \\
\hline & High workload & $125(76.7 \%)$ & $22(64.7 \%)$ & $147(74.6 \%)$ & 0.144 \\
\hline & $\begin{array}{l}\text { Materials (forms) are not available in the } \\
\text { clinic }\end{array}$ & $135(82.3 \%)$ & $26(76.5 \%)$ & $161(81.3 \%)$ & 0.426 \\
\hline & $\begin{array}{l}\text { Arabic version of materials (forms) are } \\
\text { not available in the clinic }\end{array}$ & $132(79.5 \%)$ & $25(75.8 \%)$ & $157(78.9 \%)$ & 0.629 \\
\hline & I am not trained to use WAAP & $54(33.1 \%)$ & $5(15.6 \%)$ & $59(30.3 \%)$ & 0.049 \\
\hline & $\begin{array}{l}\text { I am not aware about the } \\
\text { recommendations for providing WAAP }\end{array}$ & $40(24.2 \%)$ & $2(6.1 \%)$ & $42(21.2 \%)$ & 0.020 \\
\hline & $\begin{array}{l}\text { I think that verbal instructions is enough } \\
\text { for my patients }\end{array}$ & $43(25.9 \%)$ & $10(29.4 \%)$ & $53(26.5 \%)$ & 0.673 \\
\hline & This is the work of Asthma educator & $49(29.5 \%)$ & $12(35.3 \%)$ & $61(30.5 \%)$ & 0.505 \\
\hline & This is the work of nurse & $9(5.5 \%)$ & $4(11.8 \%)$ & $13(6.6 \%)$ & 0.245 \\
\hline & $\begin{array}{l}\text { Majority of my patients have low level of } \\
\text { education }\end{array}$ & $48(29.4 \%)$ & $12(37.5 \%)$ & $60(30.8 \%)$ & 0.367 \\
\hline & $\begin{array}{l}\text { Majority of my patients are not adhering } \\
\text { to the plans }\end{array}$ & $64(38.8 \%)$ & $20(58.8 \%)$ & $84(42.2 \%)$ & 0.031 \\
\hline & $\begin{array}{l}\text { The WAAP is not beneficial for the } \\
\text { patients with asthma }\end{array}$ & $10(6.1 \%)$ & $4(11.8 \%)$ & $14(7.0 \%)$ & 0.266 \\
\hline
\end{tabular}

Table 5 shows the results of univariate and multivariate logistic regression analysis of potential predictors of providing WAAP. In univariate analysis, older age, non-Saudi nationality, combined working in booked and triage 
clinics, longer years of experience, larger number of patients encountered per month, managing patients with asthma, and non-adherence of patients to the plans were significantly associated with providing WAAP while lack of physician training to use WAAP and lack of physician awareness with WAAP recommendations were significantly associated with not providing WAAP. In multivariate logistic regression analysis, larger number of patients encountered per month and non-adherence of patients to the plans were significantly associated with providing WAAP. The odds ratios (ORs) were 1.02 (95\% C 1.01-1.04, $\mathrm{p}=0.009)$ and $3.33(95 \% \mathrm{C} 1.40-7.87$, $\mathrm{p}=0.006$ ). On the other hand, lack of awareness with WAAP recommendations was significantly associated with not providing WAAP $(\mathrm{OR}=0.19,95 \%$ CI $0.04-0.89, \mathrm{p}=0.035)$.

Table 5. Univariate and multivariate* logistic regression analysis of potential predictors of providing written asthma action plan (WAAP) for patients with asthma $(\mathrm{n}=202)$

\begin{tabular}{|c|c|c|c|c|c|c|c|c|c|}
\hline \multirow{3}{*}{\multicolumn{2}{|c|}{ Variables }} & \multicolumn{4}{|c|}{ Univariate analysis } & \multicolumn{4}{|c|}{ Multivariate analysis** } \\
\hline & & \multirow{3}{*}{$\begin{array}{l}\text { Odds } \\
\text { ratio } \\
\text { (OR) }\end{array}$} & \multicolumn{2}{|c|}{$\begin{array}{l}95 \% \text { confidence } \\
\text { interval of OR }\end{array}$} & \multirow[t]{2}{*}{$\begin{array}{l}\mathrm{p}- \\
\text { value }\end{array}$} & \multirow{2}{*}{$\begin{array}{l}\text { Odds } \\
\text { ratio } \\
\text { (OR) }\end{array}$} & \multicolumn{2}{|c|}{$\begin{array}{l}95 \% \text { confidence } \\
\text { interval of OR }\end{array}$} & \multirow[t]{2}{*}{$\begin{array}{l}\mathrm{p}- \\
\text { value }\end{array}$} \\
\hline & & & Lower & Upper & & & Lower & Upper & \\
\hline \multirow[t]{3}{*}{ Age } & & & & & 0.025 & & & & \\
\hline & $35-45$ vs. $<35$ & 2.91 & 1.17 & 7.23 & 0.021 & & & & \\
\hline & $>45$ vs. $<35$ & 3.36 & 1.28 & 8.86 & 0.014 & & & & \\
\hline Nationality & $\begin{array}{l}\text { Non-Saudi vs. } \\
\text { Saudi } \\
\end{array}$ & 2.31 & 1.10 & 4.88 & 0.028 & & & & \\
\hline \multirow{3}{*}{$\begin{array}{l}\text { Working } \\
\text { clinic }\end{array}$} & & & & & 0.082 & & & & \\
\hline & $\begin{array}{l}\text { Triage versus } \\
\text { booked }\end{array}$ & 1.68 & 0.75 & 3.80 & 0.209 & & & & \\
\hline & $\begin{array}{l}\text { Both triage and } \\
\text { booked versus } \\
\text { booked alone }\end{array}$ & 3.43 & 1.12 & 10.52 & 0.031 & & & & \\
\hline \multicolumn{2}{|c|}{ Duration of experience (years) } & 1.04 & 1.00 & 1.08 & 0.040 & & & & \\
\hline \multicolumn{2}{|c|}{$\begin{array}{l}\text { Number of patients encountered } \\
\text { per month }\end{array}$} & 1.02 & 1.00 & 1.04 & 0.017 & 1.02 & 1.01 & 1.04 & 0.009 \\
\hline \multicolumn{2}{|c|}{ Managing patients with asthma } & 2.95 & 0.67 & 13.07 & 0.154 & & & & \\
\hline \multirow{2}{*}{\multicolumn{2}{|c|}{$\begin{array}{l}\text { Lack of training to use WAAP } \\
\text { Lack of awareness with WAAP } \\
\text { recommendations }\end{array}$}} & 0.37 & 0.14 & 1.03 & 0.056 & & & & \\
\hline & & 0.20 & 0.05 & 0.88 & 0.033 & 0.19 & 0.04 & 0.89 & 0.035 \\
\hline \multicolumn{2}{|c|}{$\begin{array}{l}\text { Non-adherence of patients to } \\
\text { the plans }\end{array}$} & 2.25 & 1.06 & 4.78 & 0.034 & 3.33 & 1.40 & 7.87 & 0.006 \\
\hline
\end{tabular}

* Multivariate logistic regression was done using backward elimination ** Multivariate logistic regression was adjusted for age, nationality, working clinic, duration of experience, number of patients encountered per month, managing patients with asthma, lack of training to use WAAP, lack of awareness with WAAP recommendations, and non-adherence of patients to the plans

\section{Discussion}

The current study examined the prevalence of providing WAAP and its perceived barriers by family physicians at primary care setting in Saudi Arabia. Only 16.8\% of physicians were providing WAAP for their patients with asthma and only $6.8 \%$ of the total number of patients seen by the study physicians was receiving WAAP. We could not compare the findings of the current study with the rates of utilization of WAAP in Saudi Arabia due to absolute lack of similar studies. Nevertheless, the current utilization of WAAP by primary care physicians is generally comparable to the rates reported in similar international studies (16-18). For example, $16.8 \%$ of family physicians in the current study were providing WAAP for their patients with asthma compared with $16.4 \%$ of primary care physicians in the USA (16), $25.7 \%$ of general practitioners in Italy (17), and $4 \%$ of primary care physicians in Canada (18). Moreover, the current rate of utilization of WAAP by the patients with asthma managed in this study (6.8\%) was similar or lower than similar international studies; which ranged between $5.2 \%$ and $39 \%$ in different settings $(19,22,23)$. The suboptimal utilization of WAAP observed in the current and international studies continued to happen despite the fact that national and international guidelines strongly recommend the use of WAAP as an effective tool to facilitate self-management in patients with asthma $(3,4)$. The suboptimal utilization of WAAP observed in the current study is consistent with the high prevalence of uncontrolled asthma among asthmatic 
patients in Saudi Arabia (7-9) and the high rates of recurrent asthma attacks which require emergency and hospital admission in Saudi Arabia $(24,25)$.

The barriers that were highly recognized by family physicians in the current study included lack of forms in the clinic including forms in Arabic, high workload, lack of time to write WAAP in the clinic, and non-adherence of the majority of patients to management plans. Likewise, a number of similar barriers have been described in different studies to discourage physicians from providing WAAP for patients with asthma $(20,21,26,27)$. For example, the time pressure, the lack of resources, poor clinic attendance of patients, and poor demarcation of professional roles were considered barriers to using WAAP at a primary care setting in the United Kingdom (20). Additionally, lack of patient interest and motivation in engagement, poor electronic resources, and lack of engagement and training of pharmacists and nurses were considered barriers to using WAAP in the primary care setting in Australia (21). Lack of forms in the clinic including forms in Arabic was the highest recognized barrier for WAAP utilization by family physicians. This may highlight the importance of electronic integration of patient charts which has been shown to improve the utilization of WAAP and outcomes of asthma management $(21,26,28)$.

Lack of physician awareness and training concerning WAAP recommendations were significantly associated with not providing WAAP for patients with asthma in the current study. Similarly, it has been suggested that limited awareness of physicians with asthma management guidelines and unfamiliarity with new medications can lead to inadequate implementation of the national protocol for management of asthma $(12,29)$. More than a quarter of the family physicians in the current study believed that verbal instructions are enough for advising patients with asthma in regard to their management plans. The same belief was expressed by general practitioners in Singapore who preferred verbal instructions over WAAP as a personalized form of asthma management strategy (27).

Interestingly, more than $90 \%$ of family physicians in the current study believed that WAAP is beneficial for patients with asthma. In the same time, lack of awareness and training regarding WAAP recommendations was associated with lower utilization of WAAP among family physicians in the current study. Both findings may indicate that the observed underutilization of WAAP is a reflection of limited education and training rather than negative attitude of physicians about the benefits of WAAP. Therefore, the findings underscore the importance of providing education and training for family physicians in Saudi Arabia regarding the use of WAAP as a tool for improving asthma selfmanagement. Several local studies pointed to the inadequate awareness of primary care physicians in Saudi Arabia with asthma management guidelines $(12,29,30)$. Additionally, providing training for primary care physicians has been suggested to improve adherence to national asthma management guidelines in Saudi Arabia $(11,12,30)$.

This study is considered the first study to examine the prevalence of providing WAAP and its perceived barriers among family physicians at primary care setting in Saudi Arabia. Nevertheless, we acknowledge few limitations. For example, as the study used a cross-sectional design, recall bias cannot be excluded and causal association cannot be determined. Being a single institution experience may limit the generalizability of the findings to Saudi primary care services. However, we believe that these limitations have minor impact on the study findings (if any) and are almost always present in similar studies.

\section{Conclusions}

In conclusion, consistent with previous reports, the current findings confirm the low utilization of WAAP at primary care setting in Saudi Arabia. The observed underutilization of WAAP is a reflection of limited education and training rather than negative attitude about the benefits of WAAP. The findings underscore the need to raise the awareness of family physicians with WAAP recommendations and the need to rectify some of its work flow issues.

Acknowledgments:

Thanks for all staff at the family medicine department at Prince Sultan Military Medical City, Riyadh, Saudi Arabia.

\section{Conflict of Interest:}

There is no conflict of interest to be declared.

Authors' contributions:

All authors contributed to this project and article equally. All authors read and approved the final manuscript. 


\section{References:}

1) GBD 2015 Chronic Respiratory Disease Collaborators: Global, regional, and national deaths, prevalence, disability-adjusted life years, and years lived with disability for chronic obstructive pulmonary disease and asthma, 1990-2015: a systematic analysis for the Global Burden of Disease Study 2015. Lancet Respir Med 2017, 5(9):691-706.

2) Ehteshami-Afshar S, FitzGerald JM, Doyle-Waters MM, Sadatsafavi M: The global economic burden of asthma and chronic obstructive pulmonary disease. Int J Tuberc Lung Dis 2016, 20(1):11-23. doi: 10.5588/ijtld.15.0472, PMid: 26688525

3) Global Initiative for Asthma: Global Strategy for Asthma Management and Prevention. Available from: https://ginasthma.org/wp-content/uploads/2019/06/GINA-2019-main-report-June-2019-wms.pdf (Accessed Januray 1, 2020). 2019.

4) Al-Moamary MS, et al. The Saudi Initiative for Asthma - 2019 Update: Guidelines for the diagnosis and management of asthma in adults and children. Annals of thoracic medicine 2019, 14(1):3-48. doi: 10.4103/atm.ATM_327_18, PMid: 30745934, PMCid: PMC6341863

5) Mohamed Hussain S, Ayesha Farhana S, Mohammed Alnasser S. Time Trends and Regional Variation in Prevalence of Asthma and Associated Factors in Saudi Arabia: A Systematic Review and Meta-Analysis. Biomed Res Int 2018, 2018:8102527. doi: 10.1155/2018/8102527, PMid:29951546m PMCid: PMC5989288

6) Mirzaei M, Karimi M, Beheshti S, Mohammadi M. Prevalence of asthma among Middle Eastern children: A systematic review. Medical journal of the Islamic Republic of Iran 2017, 31:9. doi: 10.18869/mjiri.31.9

7) BinSaeed AA et al. Determinants of asthma control among children in Saudi Arabia. J Asthma 2014, 51(4):435-9. doi: 10.3109/02770903.2013.876649, PMid: 24344812

8) BinSaeed AA. Asthma control among adults in Saudi Arabia. Study of determinants. Saudi Med J 2015, 36(5):599-604. doi: 10.15537/smj.2015.5.10929, PMid: 25935182, PMCid: PMC4436758

9) Torchyan AA. Asthma control in Saudi Arabia: Gender implications. Allergy Asthma Proc 2017, 38(3):4753. doi: 10.2500/aap.2017.38.4035, PMid: 28441984

10) Al-Jahdali $\mathrm{HH}$ et al. Perception of the role of inhaled corticosteroids and factors affecting compliance among asthmatic adult patients. Saudi medical journal 2007, 28(4):569-73.

11) Abudahish A, Bella H. Adherence of primary care physicians in Aseer region, Saudi Arabia to the National Protocol for the Management of Asthma. Eastern Mediterranean health journal = La revue de sante de la Mediterranee orientale $=$ al-Majallah al-sihhiyah li-sharq al-mutawassit 2010, 16(2):171-5. doi: 10.26719/2010.16.2.171, PMid: 20799570

12) Alrabiah AM, Elsaid T, Tourkmani A. Determinants of family medicine physicians' knowledge and application of asthma management guidelines at primary healthcare centers in Riyadh, Saudi Arabia. J Family Med Prim Care 2018, 7(5):927-36.

13) Lakupoch K, Manuyakorn W, Preutthipan A, Kamalaporn H. The effectiveness of newly developed written asthma action plan in improvement of asthma outcome in children. Asian Pacific journal of allergy and immunology 2018, 36(2):88-92.

14) Davis J, Fitzmaurice L. Providing individualized written asthma action plans during the pediatric emergency department visit. The Journal of asthma: official journal of the Association for the Care of Asthma 2020:1-6. doi: 10.1080/02770903.2020.1731824

15) Goronfolah L, Abulaban A, Barnawi AI, Jawi M, Alhadhrami W, Baatiah NY. The Effectiveness of Written Asthma Action Plan at the National Guard Health Affairs' Asthma Clinic. Cureus 2019, 11(11):e6247. doi: 10.7759/cureus.6247, PMid: 31890443, PMCid: PMC6935338

16) Cloutier MM et al. Clinician Agreement, Self-Efficacy, and Adherence with the Guidelines for the Diagnosis and Management of Asthma. J Allergy Clin Immunol Pract 2018, 6(3):886-894 e884. doi: 10.1016/j.jaip.2018.01.018, PMid: 29408439, PMCid: PMC5948143

17) Braido $\mathrm{F}$ et al. Asthma management failure: a flaw in physicians' behavior or in patients' knowledge? J Asthma 2011, 48(3):266-74. doi: 10.3109/02770903.2011.555040, PMid: 21381864

18) Djandji $F$ et al. Enablers and determinants of the provision of written action plans to patients with asthma: a stratified survey of Canadian physicians. NPJ Prim Care Respir Med 2017, 27(1):21. doi: 10.1038/s41533017-0012-3, PMid: 28364118, PMCid: PMC5434790

19) Sulaiman $\mathrm{N}$ et al. Written Asthma Action Plans (WAAPs) in Melbourne general practices: a sequential mixed methods study. Prim Care Respir J 2011, 20(2):161-169. doi: 10.4104/pcrj.2011.00010, PMid: 21336464, PMCid: PMC6549813 
20) Morrow $S$ et al. Exploring the perspectives of clinical professionals and support staff on implementing supported self-management for asthma in UK general practice: an IMP(2)ART qualitative study. NPJ Prim Care Respir Med 2017, 27(1):45. doi: 10.1038/s41533-017-0041-y, PMid: 28720751, PMCid: PMC5515882

21) Watkins K, Fisher C, Misaghian J, Schneider CR, Clifford R. A qualitative evaluation of the implementation of guidelines and a support tool for asthma management in primary care. Asthma Res Pract 2016, 2:8. doi: 10.1186/s40733-016-0023-9, PMid: 27965776, PMCid: PMC5142429

22) Camargo CA et al. A prospective multicenter study of written action plans among emergency department patients with acute asthma. The Journal of asthma: official journal of the Association for the Care of Asthma 2008, 45(7):532-8. doi: 10.1080/02770900801978573, PMid: 18773321, PMCid: PMC3526108

23) Sun Y, In D, Kim J. Asthma Care Practices of Pediatricians in Incheon, Korea and Adherence to Asthma Guidelines. Journal of Allergy and Clinical Immunology 2006, 117(2):S277. doi: 10.1016/j.jaci.2005.12.1146

24) Moradi-Lakeh $M$ et al. Prevalence of asthma in Saudi adults: findings from a national household survey, 2013. BMC Pulm Med 2015, 15:77. doi: 10.1186/s12890-015-0080-5, PMid: 26216220, PMCid: PMC4517561

25) Alzaabi A et al. Cross-sectional study on Asthma Insights and Management in the Gulf and Russia. Allergy Asthma Proc 2018, 39(6):430-6. doi: 10.2500/aap.2018.39.4180, PMid: 30326990, PMCid: PMC6212633

26) Roberts NJ, Evans G, Blenkhorn P, Partridge MR. Development of an electronic pictorial asthma action plan and its use in primary care. Patient Educ Couns 2010, 80(1):141-6. doi: 10.1016/j.pec.2009.09.040, PMid: 19879092

27) Tan NC, Tay IH, Ngoh A, Tan M. A qualitative study of factors influencing family physicians' prescription of the Written Asthma Action Plan in primary care in Singapore. Singapore Med J 2009, 50(2):160-4.

28) Kuhn L et al. Planning for Action: The Impact of an Asthma Action Plan Decision Support Tool Integrated into an Electronic Health Record (EHR) at a Large Health Care System. J Am Board Fam Med 2015, 28(3):382-93. doi: 10.3122/jabfm.2015.03.140248, PMid: 25957371

29) Al-Kabbaa AF, Al-Shamrani KM, Salih MA. Does the management of bronchial asthma by family physicians meet standards of the national protocol? J Family Community Med 2002, 9(3):21-5.

30) Yousef HA, Koura M, Yousef AA. Knowledge about bronchial asthma management in primary health care physicians in Al-Khobar City, Saudi Arabia. J Family Community Med 2015, 22(1):1-7. doi: 10.4103/2230-8229.149567, PMid: 25657604, PMCid: PMC4317988 